\title{
The Analysis of Corporate Social Responsibility in One of the private universities in Kurdistan Region of Iraq
}

\author{
Teba Ahmed Al-Ani \\ Faculty of Administrative Sciences and Economics, \\ Ishik University, Iraq \\ Krishna Mohan Vaddadi \\ Dept of Commerce \& Management Studies, \\ Andhra University, India \\ Navulur Krishna Surarchith \\ Faculty of Administrative Sciences and Economics, Ishik University, Iraq \& \\ (Research Scholar of Dr. B.R. Ambedkar University, India)
}

\begin{abstract}
The aim of this research paper is to analyze the corporate social responsibilities in one of private universities in Kurdistan region of Iraq. It starts with explaining the origin and the evolution of CSR, arguments with and against CSR, and then it crosses through the different views of CSR. In order to do that a quantitative method was used and a survey questionnaire from earlier research was adopted. The research setting was one of the private universities in Kurdistan region of Iraq, a sample of academic and administrative staff was chosen and a SPSS V. 23 has been used. As continuation to improve the work of the other researchers who analyzed the corporate social responsibility in higher educational institutions, this research paper will analyze the concept of the corporate social responsibility in universities in Kurdistan.
\end{abstract}

Keywords: Corporate social responsibility, university, corporate accountability, stakeholder's engagement, and sustainability.

\section{INTRODUCTION}

For time, not too long the concept of CSR has emerged for humanitarian issues like poverty, reducing unemployment, and activating the role of people with special needs in the process of development and integration in society and the environment in particular. This concept was missing in the past decades for multiple and complex reasons, one of the most important reasons is that placing this responsibility on the government as its the sole responsible for securing all the needs of the society at that time.

Although the bases of corporate social responsibility have a very long developing history, it's the output of the $20^{\text {th }}$ century, especially from 1920 s until now days. Although of the recently development and the publicity for CSR concept, but when we go back in time to the decades evidence about the concerns of being socially responsible, for example when we go back to six decades ago we see that according to (2) in his book "Social responsibilities of the businessman" explained that corporation do have social responsibility from the context of expanding the accountabilities for the organizations performance. In the recent decades, CSR got the attention of many thinkers and researchers, not only on the academic field but also on the business world. Corporate social responsibility considered a measuring instrument of organizations contribution in the development of the societies by capturing the values and the criteria for this measurement. The main subject of CSR is about the social working forces that 
make the organization act in a specific way and this will be done by wiping out all organizations activities that conflict with the social interests. The perception of business should have social responsibility raised before 300 years ago, when the economist and the philosopher, ADAM SMITH, explained in His book "The wealth of nations" (10) that "the support for market interactions that are freely participated in by individuals and organizations, saying that they could serve the needs of the society.

Because of the changes in the Global and Arabic world, particularly in Iraq ,Since the government is not able to fulfill all the society needs because of the unstable political and security situation that the country face, so all type of organization (Educational, economic or health) should have roles in the social responsibility activities toward the society not from the a perspective Charity , but from the point of education and community rehabilitation and providing effective mechanisms to address existing challenges and trying to find solutions to the problems that stand in the way of economic growth and long-term well-being of the society. The Higher education institutions since they are the source and the foundation for the development of societies intellectually and morally, so now they are required, more than ever, to take the responsibility toward the society by adopting CSR in their strategy, which includes conducting studies, developing measurement mechanisms, and indicators of success and this will be done by moving from the concept of volunteering to a wider application based on the concept of responsibility.

\section{LITERATURE REVIEW}

Although the bases of corporate social responsibility have a very long developing history, it's the output of the $20^{\text {th }}$ century, especially from 1920s until now days. Although of the recently development and the publicity for CSR concept, but when we go back in time to the decades evidence about the concerns of being socially responsible, for example when we go back to six decades ago we see that according to (2) in his book "Social responsibilities of the businessman" explained that corporation do have social responsibility from the context of expanding the accountabilities for the organizations performance. In the recent decades, CSR got the attention of many thinkers and researchers, not only on the academic field but also on the business world. Corporate social responsibility considered a measuring instrument of organizations contribution in the development of the societies by capturing the values and the criteria for this measurement. The main subject of CSR is about the social working forces that make the organization act in a specific way and this will be done by wiping out all organizations activities that conflict with the social interests. The perception of business should have social responsibility raised before 300 years ago, when the economist and the philosopher (ADAM SMITH ) explained in His book "The wealth of nations" (10) that "the support for market interactions that are freely participated in by individuals and organizations, saying that they could serve the needs of the society.

Since the argument about CSR started, advocators and critics begun to discussing the idea behind this argument. The researcher Friedman in 1962 (6) was one of the critics about CSR, he noted that the responsibility of business is to make profit only, and social issues solved by the un restricted work of free market. Moreover, he thinks that if free market is unable to solve these issues then legislations and governments should solve it.

The second objection made by Researcher Davis in 1973 (5) was which states that business is not prepared to deal with social issues and most of the mangers are qualifies in the financial and managerial issues. Since there are arguments against CSR, there are arguments of CSR has started and the discussion started with idea that in order to get long -term self-interest you should be socially responsible. The first argument states that if organizations want a better 
work environment in the future they should start from now taking the right actions to guarantee long -term existence. The second argument with CSR is that it will prevent future government's regulations and this seems to be logical reason because when the organizations in a specific country are socially responsible there will be no need for government regulations since organizations have the ability to discipline itself with business polices and meets the society expectations.

Researchers, Lohman \&Steinholtzgatan in the year 2004, (7) put a three dimension definitions to view CSR as a set of three different agenda, which are: It is the obligations of a company to answer stakeholders question about the responsibilities of the company toward society and environment to find solutions of activities thatits non-compliance with social standards. Is the procedure that organization follow in which it include people get effected by the decisions that organizations take or they may affect the application of the decisions, even they may support or object about a decision that they didn't find it suitable for achieving the organization objective. Is a broader term that used instead of corporate social responsibility and corporate citizenship to describe the ethical corporate practices? The goal of this business approach is to create long term consumer and employee value by following (green) strategy like protect the environment and take into consideration the corporation day -to day operation that may affect environment, social and culture. The main features of CSR are the fundamentals about CSR idea that should be included and clearly to view through the organizations social responsibilities practices so here are the six main features (characteristics) are explained briefly: Researchers defined CSR as a representative of all companies' actions that are available and even go more than what law has specified. Many of the stakeholders of companies and countries governments in the developing nations assures on these features (3).

The external factors in CSR can be referred to all type of factors that has effect on the rights of various stakeholders that are not taken into consideration in the process of making decisions of corporation, while the environmental delineation is considered as a external factors because people outside feel the effect of production process. The main subject of the stakeholder management is to recognize the stakeholder guidance depending on three features that identifies their strength, urgency and legality of appeal. therefore, by defining the guidance of stakeholders it will help in the identification and to know what are the priorities of stakeholders by following a step by step approaches starting from the inside preparations, recruiting a team of inside stakeholders to manage , marketing, communications issues and operational units, HR departments , the relationship between investors , governmental and environmental issues, developing communication skills and finally comparing the performance of stakeholders with expected performance from the organizations.(1).

The core features of CSR comes from the balancing of various stakeholders needs and interests, while CSR concept seems to go beyond the close attention of profitability from the companies and shareholder, even others believe it shouldn't but CSR conflict with profitableness.It's so obvious that CSR concept is about firms activities and the strategies that they use with social issues.The value feature in CSR consider one of the reasons why this concept is much argued, whether itwas only about companies social activities won'tbea reason of many arguments as much as the discussion of why companies do it? Research that done by (4) about the effect of personal values of mangers on organizations CSR activities. The research investigated about the relationship between CSR activities and mangers personal values. CSR is considered in some countries philanthropy or as it known as (charity work). In now days CSR is compulsory supported by rules and approved by world international standards that is moving from selfless to instrument or self-strategy. it's not considered any more as a selfless but it just more than doing charity work, since now is affectingall the organizational aspects like human resourcemanagement, marketing etc.

\section{RESEARCH OBJECTIVES}

The aim of this research is to analyze the corporate social responsibility in one of the of universities in Kurdistan region of Iraq and this will be done by knowing the universities policies toward the society , the perceptions of the employees toward the university policy and what are the activities that has been adopted by the university as a social entity. 


\section{METHODOLOGY}

In this research a quantitative method was used, a survey questionnaire was adopted from earlier research that has been done by Indian researcher Satyanarayana in the year 2013 (9).The questionnaire were distributed personally in one of the private universities in Kurdistan region of Iraq and the sample of the question included 100 persons of the academic and administrative staff and the number of respondents were 87 out of 100 which represent $87 \%$ from the total respondent and for analyzing the data SPSS software program version 23 was used.

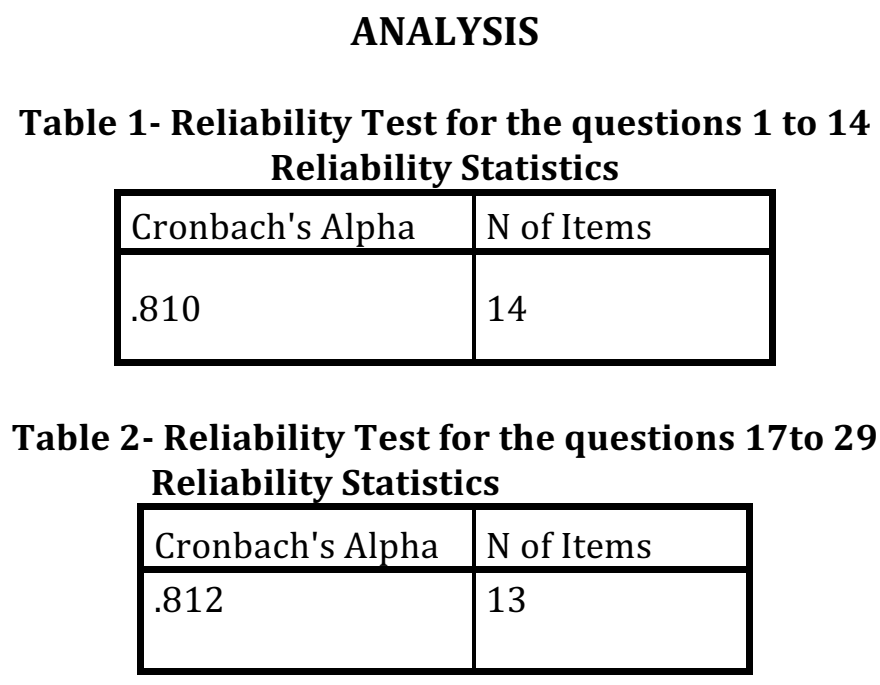

The tables above explains the reliability by using (Cronbach's Alpha) scale and the result of both tables were 0.81 for the first table and for the second table was 0.812 which are both more than the standard which is $0.7(8)$.

Table 3- demographic questions:

\begin{tabular}{|c|c|c|c|}
\hline \multicolumn{2}{|l|}{ Items } & Frequency & Percent \\
\hline \multirow[t]{2}{*}{ Gender } & Male & 59 & 67.8 \\
\hline & Female & 28 & 32.2 \\
\hline \multirow[t]{5}{*}{ AGE } & $20-30$ & 43 & 49.4 \\
\hline & $30-40$ & 31 & 35.6 \\
\hline & $40-50$ & 9 & 10.3 \\
\hline & $50-60$ & 3 & 3.4 \\
\hline & Above 60 & 1 & 1.1 \\
\hline \multirow[t]{5}{*}{ Position } & Lecturer & 44 & 50.6 \\
\hline & Head of the department & 11 & 12.6 \\
\hline & Dean of the faculty & 5 & 5.7 \\
\hline & Administrators & 8 & 9.2 \\
\hline & Other & 19 & 21.8 \\
\hline \multirow[t]{3}{*}{ Educational level } & Bachelor degree & 32 & 36.8 \\
\hline & Master degree & 34 & 39.1 \\
\hline & $\mathrm{PhD}$ & 19 & 21.8 \\
\hline Total & & 87 & $100 \%$ \\
\hline
\end{tabular}




\begin{tabular}{|c|c|c|c|}
\hline \multicolumn{2}{|l|}{ Table 4: CSR policies: } & \multirow[b]{2}{*}{ Frequency } & \multirow[b]{2}{*}{ Percent } \\
\hline Parameter & & & \\
\hline \multirow{4}{*}{$\begin{array}{l}\text { 1) Does the organization having a CSR } \\
\text { structure? }\end{array}$} & YES & 50 & 57.5 \\
\hline & NO & 8 & 9.2 \\
\hline & DON'T KNOW & 28 & 32.2 \\
\hline & NOT APPLICABLE & 1 & 1.1 \\
\hline \multirow{4}{*}{$\begin{array}{l}\text { 2) Do your employees get encouragement to } \\
\text { participate in local community activities for } \\
\text { example (providing employee time and } \\
\text { expertise, or other practical help)? }\end{array}$} & YES & 68 & 78.2 \\
\hline & NO & 7 & 8.0 \\
\hline & DON'T KNOW & 10 & 11.5 \\
\hline & $\begin{array}{l}\text { NOT } \\
\text { APPLICABLE }\end{array}$ & 2 & 2.3 \\
\hline \multirow{4}{*}{$\begin{array}{l}\text { 3) Does your enterprise give regular financial } \\
\text { support to local activities and projects like } \\
\text { charitable donations or sponsorships)? }\end{array}$} & YES & 62 & 71.3 \\
\hline & NO & 9 & 10.3 \\
\hline & DON'T KNOW & 15 & 17.2 \\
\hline & NOT APPLICABLE & 1 & 1.1 \\
\hline \multirow{4}{*}{$\begin{array}{l}\text { 4)Do you communicate your enterprise's } \\
\text { values to customers, business partners, } \\
\text { suppliers and other interested }\end{array}$} & YES & 36 & 41.4 \\
\hline & NO & 16 & 18.4 \\
\hline & DON'T KNOW & 31 & 35.6 \\
\hline & NOT APPLICABLE & 4 & 4.6 \\
\hline \multirow{4}{*}{$\begin{array}{l}\text { 5) Does your Company make an assessment of } \\
\text { impact of its business on the stake holders? }\end{array}$} & YES & 35 & 40.2 \\
\hline & NO & 15 & 17.2 \\
\hline & DON'T KNOW & 35 & 40.2 \\
\hline & NOT APPLICABLE & 2 & 2.3 \\
\hline \multirow{4}{*}{$\begin{array}{l}\text { 6) Does your Company study the impact of its } \\
\text { CSR activities on stakeholders? }\end{array}$} & YES & 35 & 40.2 \\
\hline & NO & 13 & 14.9 \\
\hline & DON'T KNOW & 38 & 43.7 \\
\hline & NOT APPLICABLE & 1 & 1.1 \\
\hline \multirow{2}{*}{$\begin{array}{l}\text { 7) Based on your experience, would you agree } \\
\text { the corporation is an instrument for wealth }\end{array}$} & YES & 47 & 54.0 \\
\hline & NO & 10 & 11.5 \\
\hline
\end{tabular}




\begin{tabular}{|c|c|c|c|}
\hline \multirow[t]{2}{*}{$\begin{array}{l}\text { creation with CSR conceived as a strategic tool } \\
\text { to promote economic objectives? }\end{array}$} & DON’T KNOW & 28 & 32.2 \\
\hline & NOT APPLICABLE & 2 & 2.3 \\
\hline \multirow{4}{*}{$\begin{array}{l}\text { 8) Do you agree: CSR is an unconditionally } \\
\text { acceptance obligation of Business? }\end{array}$} & YES & 44 & 50.6 \\
\hline & NO & 14 & 16.1 \\
\hline & DON'T KNOW & 25 & 28.7 \\
\hline & NOT APPLICABLE & 4 & 4.6 \\
\hline \multirow{4}{*}{$\begin{array}{l}\text { 9) Does your Company make an assessment of } \\
\text { impact of its business on the stake holders? }\end{array}$} & YES & 55 & 63.2 \\
\hline & NO & 9 & 10.3 \\
\hline & DON'T KNOW & 19 & 21.8 \\
\hline & NOT APPLICABLE & 4 & 4.6 \\
\hline \multirow{4}{*}{$\begin{array}{l}\text { 10) Do you agree: Government should provide } \\
\text { training to companies to help them to } \\
\text { implement CSR? }\end{array}$} & YES & 52 & 59.8 \\
\hline & NO & 13 & 14.9 \\
\hline & DON'T KNOW & 19 & 21.8 \\
\hline & NOT APPLICABLE & 3 & 3.4 \\
\hline \multirow{4}{*}{$\begin{array}{l}\text { 11) There should be more public recognition } \\
\text { given to companies doing well in the area of } \\
\text { CSR? }\end{array}$} & YES & 45 & 51.7 \\
\hline & NO & 16 & 18.4 \\
\hline & DON'T KNOW & 22 & 25.3 \\
\hline & NOT APPLICABLE & 4 & 4.6 \\
\hline \multirow{4}{*}{$\begin{array}{l}\text { 12) Do you agree with CSR budgets allocated } \\
\text { by your company? }\end{array}$} & YES & 38 & 43.7 \\
\hline & NO & 13 & 14.9 \\
\hline & DON'T KNOW & 33 & 37.9 \\
\hline & NOT APPLICABLE & 3 & 3.4 \\
\hline \multirow{4}{*}{$\begin{array}{l}\text { 13) Do you agree with the geographical area of } \\
\text { CSR interventions? }\end{array}$} & YES & 37 & 42.5 \\
\hline & NO & 12 & 13.8 \\
\hline & DON'T KNOW & 30 & 34.5 \\
\hline & NOT APPLICABLE & 8 & 9.2 \\
\hline \multirow[b]{2}{*}{ Q14) Do you agree with the nature of CSR } & YES & 41 & 47.1 \\
\hline & NO & 16 & 18.4 \\
\hline
\end{tabular}




\begin{tabular}{|l|l|c|c|}
\hline activities undertaken by Your Company? & DON’T KNOW & 24 & 27.6 \\
\cline { 2 - 4 } & NOT APPLICABLE & 6 & 6.9 \\
\hline
\end{tabular}

The above table explains the university's policies towards the society, and the highest percent of the responses was with yes while the other chosen either don't know or not applicable.

Q15) Please state any tool through which CSR was popularized?

Table (5)

\begin{tabular}{|l|c|c|}
\hline Name of the item & $\begin{array}{c}\text { No. of } \\
\text { respondents }\end{array}$ & $\mathbf{\%}$ \\
\hline News bulletins & 24 & 27.5862069 \\
\hline Reports & 30 & 34.48275862 \\
\hline Weekly News Video Magazine & 24 & 27.5862069 \\
\hline Newspapers & 16 & 18.3908046 \\
\hline Websites & 55 & 63.2183908 \\
\hline Others & 10 & 11.49425287 \\
\hline
\end{tabular}

\section{Q16) Please state CSR activities of your organization relating to the following:}

Table (6)

\begin{tabular}{|l|c|c|}
\hline Name of the item & No. of respondents & $\mathbf{\%}$ \\
\hline Environmental Care & 50 & 57.47126437 \\
\hline Healthcare & 30 & 34.48275862 \\
\hline Housing & 14 & 16.09195402 \\
\hline Community Involvement & 26 & 29.88505747 \\
\hline Rural Sports & 51 & 58.62068966 \\
\hline Education & 71 & 81.6091954 \\
\hline Peripheral Development & 9 & 10.34482759 \\
\hline Village adoption & 10 & 11.49425287 \\
\hline Employment \& Employability & 23 & 26.43678161 \\
\hline Welfare & 18 & 20.68965517 \\
\hline
\end{tabular}

\section{DISCUSSION}

This research conclude that the highest percent of the answers were positive, regarding wither the university have a CSR structure or not, encouraging the employees to participate in activities of the society, providing financial support to them, wither it communicates the enterprises values to the students or its stakeholders and whether they were satisfied or not with the nature of CSR actives, the geographical area of CSR was implemented and about the budget allocated by the university, while the second part of the questionnaire concluded that $63.2 \%$ of the respondents said that the first time they got introduced to CSR was through websites, $34.4 \%$ said it was through reports, $27.5 \%$ was through news bulletins and weekly new videos magazine , $18.3 \%$ said newspaper and the percentage of $11.4 \%$ belonged to "other tools". According to the activities that the university adapts as a corporate that is socially responsible, answers shows that $81.6 \%$ of the university's activities were toward the educational part, 58.6\% were rural sports, 57.4\% environmental care, 34.4\% health care, 29.8 community involvement, 26.4\% employment and employability, 20.6\% welfare, $16.09 \%$ housing, $11.4 \%$ village adaption and $10.3 \%$ were peripheral development. 


\section{CONCLUSION}

Till the late in Kurdistan region the universities was only responsible for education and developing the students skill but with the educational institutions being characterized by various developments, universities now days are forced to be responsible not only toward education but also society, due to the faster communication, faster traveling means and the geographical boundaries shrinking people are becoming more aware of the responsibilities they have toward the organizations and society in general and the responsibility that the society and the organizations itself has towards them. Educational institutions depend on society for their existence so it is in their interest to take care of society. The purpose of this research is analyze the corporate social responsibility in one of the private universities in Kurdistan region of Iraq by asking the academic and the administrative staff of that selected university .The concept of CSR has been introduced in the late of 1920s and in the recent decades, CSR got the attention of many thinkers and researchers, not only on the academic field but also on the business world, from those thinkers were many critics and advocators begun to discussing the idea behind this concept. Researchers Put a three dimension definitions to view CSR which were (corporate accountability, stakeholder engagement and sustainability) as a set of three different agenda. The research objectives was set in order to explain the effect of the university as a social entity on the society, since its created by the society and for the society and this was done by examining the university policies toward the society, that starts from asking the employees inside the university which included the academic and the administrative staff. In this research the data was collected by selfadministrated questionnaire that has been distributed personally to the staff and employees directly by the researcher, the questionnaire included four types of questions and all of them were close-ended questions, for the data analysis part, data was analyzed by using both SPSS and excel software to get the result from the respondent response.

\section{ACKNOWLEDGMENT}

Authors would like to thank Ishik University, Erbil, Northern Iraq for supporting current research.

\section{References}

Ahmad, A., Murtala, I., \& Bashiru, D. (2014). Exploring the Roles of Stakeholder Engagement and Stakeholder Management in CSR Practice. Australian Journal of Business and Management Research, 1-8.

Bowen, H. (1953). Social responsibilities of the businessman. New york: Harper \& Brothers.

Crane, A., Matten, D., \& Spence, L. (2008). Corporate social responsibility: Readings and cases in a global context, 2nd edition. London: Routledge.

Duarte, F. (2010). Working with Corporate Social Responsibility in Brazilian Companies: The Role of Managers' Values in the Maintenance of CSR Cultures. Journal of Business ethics Volume 96, 355-368.

Davis. (1973). The case for and against business assumption. Academy of Management, 312-322.

Friedman, M. (1962). The social responsibility of business is to increase its profits. New York Times Magazine, 133.

Lohman, ,.. \& Steinholtzgatan, ,. (2004). Corporate Responsibility - Corporate Social Responsibility. Ekerlids publishers, 15-16.

Nunnally, J. C. (1978). Psychometric theory (2nd ed.). New York: McGraw-Hill

Satyanarayana, P. (2013). Corporate social responsibilities: a study of selected organizations. Shodhganga center, 82 - 131 .

Smith, A. (1776). The wealth of nations. Great Britain: W. Strahan and T. Cadell, London. 